2021 TheoLogica

An International Journal for Philosophy of Religion and Philosophical Theology

ORIGINAL PAPER

DOI: https://doi.org/10.14428/thl.v5i2.20343

\title{
Let's Play GOLF!
}

\section{Or, The Free Will Defense Is Dead}

\author{
STEVEN B. COWAN \\ Lincoln Memorial University \\ steven.cowan@1munet.edu
}

\begin{abstract}
A central feature of the "free will defense" as developed by Alvin Plantinga is his response to the claim that God can create a world containing creatures with libertarian freedom that contains no moral evil. Plantinga's response appeals to the notion of "morally significant freedom" according to which free creatures, in order to do moral good, must be capable of moral evil. In this paper, I argue, first, that morally significant freedom is not required for free creatures to do moral good and, second, that other recent attempts to necessitate a creaturely capability for evil likewise fail. The upshot of my paper is that the free will defense simply won't work because it is possible and feasible for God to create a world containing libertarianly free creatures capable of moral good and yet containing no moral evil.
\end{abstract}

Keywords: Problem of Evil, Free Will Defense, Alvin Plantinga, Libertarianism, Theodicy

The logical problem of evil is, broadly, the problem of accounting for the existence of evil in a world created by an omnipotent, omniscient, omnibenevolent God. More narrowly, the problem has to do with moral evil (i.e., evil caused by the choices and actions of moral agents), as distinguished from natural evil (the suffering and pain caused by such things as earthquakes, diseases, etc.). My focus in this paper is entirely on the logical problem of moral evil (though I will typically use the broad expression "logical problem of evil" for simplicity's sake). Used as an argument against the existence of God, the problem is an attempt to demonstrate that the proposition

(1) Moral evil exists

is logically incompatible with 
(2) God exists.

J. L. Mackie is the philosopher most famous for attempting such a demonstration (Mackie 1955). The gist of his case lies in the claim that God, being omnipotent and perfectly good, could and would actualize a possible world containing free creatures who always choose to do what is morally right. Since the actual world is not such a world - the actual world contains moral evil-it follows that God does not exist.

Alvin Plantinga, though, has powerfully argued that Mackie's central claim is false (Plantinga 1974). In his now iconic free will defense (FWD), Plantinga argues that it is not necessarily the case that God can actualize a world containing creatures with libertarian freedom who are capable of morally good actions and who always do what is morally right. Whether or not God can actualize such a world depends, he claims, on what the free creatures that exist in that possible world would do. This contingency implies that it is logically possible that any and every free creature that God can create suffers from what Plantinga calls transworld depravity - that for any free creature $S$ and any possible world $W$ containing $S$ that God can create, $S$ goes wrong with regard to at least one morally significant action. So, while it is logically possible for God to create or actualize a possible in world in which libertarianly free creatures always choose rightly, it is also logically possible that such a world is not feasible for God, ${ }^{1}$ since its feasibility depends upon what choices the creatures in that possible world would actually make. The possibility of transworld depravity, then, leads Plantinga to assert that it is possible that it was not within God's power to create a world containing creatures with libertarian freedom (or, as we will see below, the right kind of libertarian freedom) who always do what is morally right. Given that a world containing free creatures might nonetheless be a valuable world, it would seem to follow, contra Mackie, that God's existence is logically compatible with the existence of moral evil after all.

The key idea in FWD, of course, is the denial, or perhaps nullification, of Mackie's central claim that God can actualize a possible world containing creatures with libertarian freedom who always choose to do what is morally right. In this paper, I will develop the case that this key idea of FWD is false. I will argue that God can, in fact, guarantee that there is a feasible world with libertarianly free creatures who always do what is morally right and that this possibility effectively undermines the

${ }^{1}$ Here I am following Thomas Flint's distinction between possible worlds and feasible worlds (Flint 2006). A possible world is feasible just in case it is consistent with whatever counterfactuals of freedom happen to be true of the free creatures in that world. 
FWD. Furthermore, I will show that attempts by Plantinga and others to argue that the libertarian freedom in such a world would not be of an adequate sort fail. ${ }^{2}$

\section{Playing GOLF!-Or, How God Can Create a World with Free Creatures Who Never Go Morally Wrong}

Peter Geach has already stated, on grounds very similar to those I wish to develop and defend in this section, that "the Free Will defense utterly fails" (Geach 2001, 87). Why? Because God could have created us in such a way that we have free choice only among good alternatives. That is, there is a feasible possible world that God can create containing agents who have libertarian freedom, but that this freedom is limited or restricted to choosing between multiple good options. Such agents thus always freely choose to perform good actions and never do anything morally evil. ${ }^{3}$

Now how might God accomplish this? How could God so restrict libertarian freedom that it always and only chooses between morally good options? Perhaps Geach thought it could be done by God hardwiring human beings in such a way that they simply never have thoughts of evil actions, but only thoughts of various good courses of action. So, the idea is that human beings, on this view, would be blissfully ignorant of - because incapable even of thinking about - the ways of evil. ${ }^{4}$

\footnotetext{
${ }^{2}$ There are, of course, other very different approaches to challenging the FWD. In particular, some philosophers (e.g., Pruss 2012 and Otte 2009) have challenged the coherence of Plantinga's notion of transworld depravity.

${ }^{3} \mathrm{~W}$. Matthews Grant has presented an argument against the FWD that bears some resemblance to the argument presented here (Grant 2019, 119-24). Grant's argument, however, depends crucially on his "extrinsic model of divine agency" (EM) according to which "God's causing or bringing about some effect within creation will not involve any real or intrinsic state or property of God that would not be there were he not causing the effect" (57). However, EM is controversial and possibly incoherent as Greg Welty has pointed out (See Welty 2020). The argument presented in this paper has the virtue of not depending on any controversial assumptions such as EM.

${ }^{4}$ Greg Welty and I, inspired by Geach, recently presented a formal argument in defense of this possibility (see Cowan and Welty 2015). The argument goes like this:
}

(1) In the actual world it is obvious that God has hardwired us so that certain thoughts that would otherwise be thinkable by us, are not in fact thinkable by us (perhaps because of their size or complexity). Perhaps angels can think these thoughts, but we cannot.

(2) Therefore, it is plausible to think that it was open to an omnipotent God to hardwire us in other ways, so that other kinds of thoughts wouldn't occur to us as well: thoughts of evil actions.

(3) If God were to so hardwire us, then there would be no moral evil whatsoever. 
Geach's proposal won't quite do, however. We may suppose that the free creatures in our hypothetical world, when they perform the morally good actions they perform, know that the actions they perform are morally good -they have, that is, moral knowledge. Certainly, it is plausible to think that knowing what is good and right entails also knowing what is bad and wrong. Thus, it would seem implausible to think that creatures even with the limited free will we are considering would be incapable of even conceiving of evil. ${ }^{5}$

This does not imply, though, that creatures with such restricted free will must be capable of doing evil. Nor does it imply that they must be capable of conceiving of doing evil. ${ }^{6}$ Modifying Geach's proposal, then, the claim is that there is a feasible possible world $\mathrm{W}$ in which God creates creatures who have libertarian freedom, but has also "wired" them in such a way that (i) they understand what it means to do a morally evil action, but (ii) they find the thought of such actions always morally repugnant, and so (iii) they never have the desire to do such actions, always preferring instead to do what is good and right, and (iv) they exercise their libertarian freedom by choosing between multiple morally good options.

Up to now, we have referred to the kind of libertarian freedom the creatures in $\mathrm{W}$ enjoy as "restricted" free will. However, in order to emphasize the precise nature of the restriction, let's call it Good Oriented Libertarian Freedom (or GOLF for short). ${ }^{7}$ So, what I contend is that there is a feasible possible world in which God creates

(4) If God were to so hardwire us, we would nevertheless satisfy both the source and leeway conditions on libertarian free will:

a. For any action we choose (among the various good actions that occur to us), we are the ultimate cause of our intending that action.

b. For any action we choose (among the various good actions that occur to us), we could have refrained from performing that action in the same exact circumstances, and performed some other action instead.

(5) Therefore, it was open to God to create an indeterministic world in which there is no moral evil, all human persons satisfy the source and leeway conditions on libertarian free will, and they always indeterministically choose the good.

5 Thus, Jerry Walls has plausibly argued against premise (2) of the argument presented by Welty and me (see note 4), by pointing out, concerning God's ethical commands to us, that " $[t]$ o understand the command to obey is to understand the possibility of disobedience" (Walls 2015, 419).

${ }^{6}$ As Welty and I argue in our reply to Walls (Welty and Cowan 2015, 433-35).

7 When I say that a libertarianly free agent may have "good-oriented" freedom, I do not have in view the "guise of the good thesis" - that is, the view that "everything an agent desires or pursues is in some way thought to be good" (Tenenbaum 2013). While the guise of the good thesis will probably be true of agents with GOLF, what matters for GOLF is that a libertarianly free agent's will be "goodoriented" in the sense that, for any action A that the agent chooses, A is either objectively morally good or morally neutral and that the agent knows that A is morally good or morally neutral. 
creatures with GOLF. If so, then it follows that God need not be hindered by transworld depravity. He can guarantee the actualization of a possible world with libertarianly free creatures who always do what is morally right. This possibility is inconsistent with the key idea behind the FWD. So, if world W-the world containing creatures with GOLF-is possible and feasible, it would seem that the FWD is dead.

It certainly seems to me that $\mathrm{W}$ is possible and feasible. ${ }^{8}$ There have been attempts, however, to defend the importance and value of "unrestricted" libertarian freedom-attempts that are either directly aimed at or tantamount to undermining the possibility of $W$. The remainder of this paper will consider and respond to three such attempts.

\section{Plantinga's Avoidance of GOLF}

Though perhaps not having anything like GOLF in mind, Plantinga himself understands the kind of free will required by his FWD in terms that preclude the possibility (or at least the relevance) of GOLF. In introducing the FWD, Plantinga writes,

A world containing creatures who are significantly free (and freely perform more good than evil actions) is more valuable, all else being equal, than a world containing no free creatures at all. Now God can create free creatures, but he cannot cause or determine them to do only what is right. For if He does so, then they aren't significantly free after all; they do not do what is right freely. (Plantinga 1974, 30, his emphasis)

The relevant notion here for my purposes is the notion of significant freedom. For Plantinga, a person is significantly free "if he is . . free with respect to a morally

\footnotetext{
${ }^{8}$ An anonymous reviewer insists that I cannot assume that GOLF-world $W$ is indeed feasible. The reviewer asserts that I need to present an argument for the claim that God is guaranteed to be able to strongly actualize such a world. I believe that the argument the reviewer wants is implicit in the description of $\mathrm{W}$. The agents therein satisfy either source or leeway conditions on free will and moral responsibility, and yet God has "wired" them in such a way that they cannot choose evil actions. Why couldn't God actualize this world? Whatever problems of feasibility infect those possible worlds in which agents have what Plantinga calls "morally significant freedom" (see section 2 below), no such problem obtains with regard to W. In actualizing W, God does not have to consider, for example, whether or not the counterfactuals of freedom pertaining to Curley and Smitty are consistent with W. For in a GOLF-world containing agents relevantly like Curley and Smitty, all of the relevant counterfactuals of freedom would pertain only to good actions.
} 
significant action" (Ibid.). And by a morally significant action he means an action that "it would be wrong for him to perform . . . but right to refrain or vice versa" (Ibid.). So Plantinga understands a person to have significant freedom only if "either the performance of [some] action or refraining from that action is morally wrong, and the person is free to act or to refrain from acting" (Pawl and Timpe 2009, 415). This leads Plantinga to go on to write, "To create creatures capable of moral good, therefore, [God] must create creatures capable of moral evil" (Plantinga 1974, 30).

It is implausible to think that Plantinga was completely unaware of the possibility of GOLF. Indeed, his introduction of the concept of significant freedom might very well imply the possibility, strictly speaking, of GOLF. But, given his use of significant freedom in the FWD, he evidently thinks (or thought) that GOLF is of little or no moral relevance. As he wrote, for creatures to be capable of moral good, they must be capable of moral evil. If true, this would imply that the kind of creaturely freedom afforded by GOLF (even if it's possible) is a kind of freedom that renders creatures unable to do moral good. And this result would certainly nullify the significance of GOLF (and the possibility of W) as a challenge to the FWD.

But why think that creatures with only GOLF would necessarily be incapable of moral good? To be sure, these creatures would not have "significant freedom" as Plantinga has defined it. But they could have what Timothy Pawl and Kevin Timpe call "morally relevant freedom" which they describe as follows:

[A] choice is morally relevant iff the person is free to choose among at least two options, and at least two of the options, say, A and B, are related such that either A is better than B or B is better than A. Similarly, we say that a person has morally relevant freedom if she is free with respect to a choice that is morally relevant to her. (Pawl and Timpe 2009, 416)

And, of course, if both A and B are morally good options, then the person with morally relevant freedom is capable of moral good without necessarily being capable of moral evil. For Plantinga to rule out world W, he would have to argue that significant freedom, as opposed to morally relevant freedom or GOLF, is somehow necessary for free creatures, or the only kind of libertarian freedom worth having, or otherwise required for some overriding good purpose that God has which cannot be accomplished with creatures who have only GOLF. To my knowledge, Plantinga has offered no such argument. ${ }^{9}$

\footnotetext{
9 Plantinga does argue elsewhere (see Plantinga 2005) that the value of a world containing incarnation and atonement could provide God with an overriding good purpose to permit moral evil. And while he does connect this purpose to the notion of significant freedom, he does not argue or
} 
So, as far as I can tell, Plantinga is simply wrong that significant freedom is necessary in order for free creatures to be capable of moral good. Morally relevant freedom is sufficient for providing the capability for moral good. And in the absence of an argument showing that morally relevant freedom is otherwise deficient or undesirable, I conclude that Plantinga's defense of the FWD fails.

\section{Howsepian's Attempt to Refrain from GOLF}

A. A. Howsepian, however, has presented an argument that has the potential to undermine GOLF. His argument is not directly designed to address GOLF. Rather, he aims to show why libertarian freedom - understood in terms closely reminiscent of Plantinga's notion of significant freedom - is preferable to compatibilist freedom (Howsepian 2008). But, if his argument is successful, it would pose a definite threat to the possibility and/or feasibility of world W and GOLF.

Howsepian's basic thesis is that without libertarian freedom human beings "could not become optimally good people" (Howsepian 2008, 202). In his view, becoming an optimally good person requires being able to refrain from doing evil, and only agents with libertarian freedom, he thinks, have such an ability.

Noting that God is necessarily good and thus incapable of evil, and that the saints in heaven will be perfectly virtuous and likewise incapable of (any further) evil, Howsepian suggests (rightly I think) that libertarian free will is not intrinsically valuable. Instead, libertarian freedom, if valuable at all, must be merely instrumentally valuable "for moral virtue acquisition" (Ibid., 206) as is supposed by typical soul-making theodicies. With this in mind, Howsepian argues that only agents with libertarian free will are capable of achieving the optimal goodness we might expect of perfectly morally virtuous agents.

His argument begins by stating that good actions may be performed in two ways, namely, by directly doing some good action and by refraining from doing some evil action. He also notes that refraining from an action requires that an agent intend not to perform that action. Howsepian then makes a claim that is crucial to his argument: "a rational agent $S$ could not intend to perform impossible 'actions' of any type if $S$ knows that 'actions' of that type were impossible" (Ibid., 209). This claim allows Howsepian to argue that agents with compatibilist freedom (given determinism) are not literally capable of refraining from actions that they perform. For "it is metaphysically impossible for $S^{*}$ [a compatibilistically free agent] actually to refrain

insist that this purpose can only be had in a world with significant freedom as opposed, say, to compatibilist freedom. Moreover, it is clear that in this case he is offering a version of the Greater Good Defense/Theodicy, not the Free Will Defense. 
from performing an 'action' that it is impossible for $S^{*}$ to perform and that $S^{*}$ knows is impossible for him to perform" (Ibid., 211, his emphasis). Further, when comparing $S^{*}$ with $S$ (a libertarianly free agent), both of whom perform some direct good action $\mathrm{A}$ and refrain from some evil action E, Howsepian concludes that $S$ performs two good actions $-A$ and $\sim E-$ while $S^{*}$ performs only one because $S^{* \prime} S$ "refraining" from $\mathrm{E}$ was only an apparent refraining not a real one.

Howsepian then proceeds to argue that only agents with libertarian freedom are capable of attaining optimal goodness. He writes,

Consider, then, two possible worlds $W_{1}$ and $W_{2}$, such that. . (c) there are some rational inhabitants of $W_{1}$ which are free in the libertarian sense, while no rational inhabitants of $W_{2}$ possess libertarian freedom, $(d)$ all free inhabitants of these worlds possess $A$-knowledge [i.e., knowledge of whether or not they possess libertarian or compatibilist free will], and (e) there exist multiple "refraining-from-evil-situations" that are accessible to at least some agents in these worlds. ... Further suppose that none of the inhabitants of $W_{1}$ or $W_{2}$ perform any evil actions. ., but perform only good actions at every opportunity. If what we have said about the relationship between libertarian freedom, determinism, $A$-knowledge, and refraining is correct, then ... the number of good actions performed by the agents in $W_{1}$ is greater than the number of good actions performed by the agents in $W_{2}$. But if this is the case, then the degree of goodness which is exemplified by the inhabitants of $W_{1}$ is greater than the degree of goodness exemplified by the inhabitants of $W_{2}$. (Ibid., 211-12)

The upshot of the argument, of course, is that only the agents in $W_{1}$-the world with libertarianly free agents - are capable of achieving optimal goodness.

It should be obvious that Howsepian's argument, if successful, would undermine the case against the FWD I have sketched above. For while my world W with its GOLF-possessing creatures might, strictly speaking, be logically possible, in that world, the free creatures would, like the compatibilistically free creatures in $W_{2}$, be incapable of refraining from evil actions as Howsepian understands refraining. And thus, world $\mathrm{W}$ is a world that God would have overriding reasons not to create, seeing as how God would, presumably, want to create a world in which creatures achieve optimal goodness. ${ }^{10}$

There are several things to say in response to Howsepian's argument, however. First, his thesis is not one that most orthodox Christians would accept. Jesus, the

${ }^{10}$ An anonymous reviewer suggests that Howsepian's argument might be challenged by appeal to the widely held view that there is no best possible world. It is not clear to me, however, that Howsepian's argument requires a denial of this view but only that there be at least one possible world in which optimal goodness is achievable. 
typical Christian believes, is impeccable. This means that not only does he perform no evil actions, he is necessarily incapable of performing evil actions. ${ }^{11}$ In fact, if Jesus has libertarian freedom at all, on this view, it must be GOLF! If Howsepian is right in his understanding of "the relationship between libertarian freedom, determinism, $A$-knowledge, and refraining," then we must either reject the impeccability of Christ or conclude that Jesus was unable to literally refrain from evil actions and thus unable to become optimally good. I suggest that this is too big a pill for the Christian to swallow and points us in the direction of understanding the nature of "refrainings" differently. ${ }^{12}$

Second, Howsepian's understanding of refraining appears to be incoherent. Consider that he stipulates early on that "both $S$ and $S^{*}$ can perform actions that are either morally good or morally evil and that both $S$ and $S^{*}$ can be morally good (or virtuous) or morally evil (or vicious) agents" (Howsepian 2008, 208). I take this to imply that Howsepian grants, at least for the sake of argument, that $S^{*}$, the agent with compatibilist freedom, is morally responsible for his direct actions whether good or bad. But why, then, is $S^{*}$ not morally responsible for his "refrainings"? Howsepian's primary reason for denying that $S^{*}$ does anything good when he "refrains" from evil act $\mathrm{E}$ is that he knows he could not have done anything other than "refrain" from evil act E, and therefore could not intend to refrain from E-and this makes it the case that he is not morally responsible for "refraining" from E. But

${ }^{11}$ The impeccability of Christ is affirmed by almost all of the orthodox divines - For example: Tertullian (De Carne Christi 16.780-81; De Anima 41.3); Origen (De Principiis 2.65; Contra Celsium 1.33; 4.15); Augustine (Sermon 284.5; “On the Spirit of the Letter 1"); Irenaeus (Adversus Haereses 3.19.3; 5.14.3); Clement of Alexandria (Paedagogus 1.6.43.3; 1.2.4.1-2); Athanasius (Oratio III contra Arianos 33; De Incarnatione 17); Basil of Caesarea (Epistle 261); Anselm (Cur Deus Homo II.10); Aquinas (Summa Theologica III.15.1-2). For a discussion of some of the classical ways in which Christ's impeccability has been defended and explained, see John E. McKinley (2011). For a contemporary defense of Christ's impeccability, see Brian Leftow (2014). Of course, some Christians maintain the heterodox view that Christ is capable of sin, though sinless. If one takes this view, however, there may still be serious problems for the free will defense as argued by Richard B. Davis and W. Paul Franks (2018).

${ }^{12}$ An anonymous reviewer suggested that Thomas Flint has offered a Molinist account of Christ's nature (see Flint 2001) that captures "all that is essential to the traditional view that Christ is impeccable while allowing that the human nature of Christ was capable of sin." Without going into the details of Flint's account, I offer two observations. First, Flint's account is successful, at best, only if a Molinist view of divine providence is true. I for one, find that highly unlikely (see Cowan 2003 and 2009). Second, though Flint's account does allow that Christ, in a sense, is incapable of sin, Flint's Christ is clearly not impeccable. On Flint's account, Christ's human nature is such that it/he can sin if placed in the right circumstances. It is only because God actualizes a world in which Christ is never placed in those circumstances in which he would freely choose to sin, that he in fact is "incapable" of sin. So, on Flint's account, Christ per se is clearly not impeccable. This is not a view of Christ's impeccability that would be attractive to those who hold the orthodox doctrine of impeccability. 
isn't this inconsistent with the idea that compatibilist agents are morally responsible for their direct actions? The compatibilist doesn't believe that agents can do otherwise than what they do when it comes to their direct actions any more than their refrainings. So, let's stipulate that $S^{*}$ knows that he cannot do other than what he does when he performs some direct action A. Wouldn't $S^{* \prime} s$ ability to intend to do $A$ be just as suspect as his having the ability to intend to do $E$ ? To be sure, $E$ is an impossible act for $S^{*}$, while it is clear that $S^{*}$ can do A. ${ }^{13}$ Yet, $S^{* \prime}$ s not doing E (refraining?) is possible, while his not doing A is impossible. It seems that the two cases are perfectly symmetrical. So, it would seem that we must either grant or deny that $S^{*}$ can have real intentions in both cases. Better, if we grant that $S^{*}$ is morally responsible for his "direct" actions, we should also grant that he is morally responsible for his "refrainings." 14

Third, for Howsepian the quantity of agents' good actions is determinative of optimal goodness. But why not say instead that optimal goodness is related to the kind of agent one is - such that an agent who cannot do evil is morally better than one who can? Indeed, Howsepian seems very (and counterintuitively) Kantian in this regard. Responding to a potential objection, he writes that

on any moral theory whatsoever, if refrainings from evil are good acts, then ceteris paribus, one who has the greater capacity (defined set theorectically) to refrain from evil exemplifies a greater degree of goodness than one who does not have that capacity.... To deny this is either to claim that the being who has the lesser capacity to refrain from evil exemplifies the greater degree of goodness (and this would be patently absurd) or that there is no difference in the degree of goodness exemplified by these two created beings. (Ibid., 212n23, his emphasis)

Howsepian says that it is "patently absurd" that the being with the lesser capacity to refrain from evil exemplifies the greater degree of goodness. I disagree. Keep in mind that to have the "lesser" capacity for refraining from evil means, for Howsepian, being unable to succumb to evil. That is, the agent who cannot do evil has the lesser capacity to refrain from evil because that agent fails to satisfy Howsepian's understanding of what it means to truly refrain. But this sounds like the counterintuitive notion attributed to Kant (at least on one standard interpretation) that an agent, say, with strong desires to do evil but who successfully resists doing

\footnotetext{
${ }^{13}$ I owe this point to an anonymous reviewer.

${ }^{14}$ Another way to characterize the point being made here is that I'm calling into question the distinction between direct actions and refrainings as Howsepian understands them. In my view, a "refraining" is as much a doing as what he calls a direct action.
} 
evil is morally better and more praiseworthy than an agent with a stable morally virtuous character that finds it relatively easy to resist evil. But this is contrary to the value that we place on having a virtuous character. If Kant (and Howsepian) are right, then why prefer a virtuous character at all? For that matter, Howsepian's view would imply that Jesus (understood as impeccable) would necessarily have a lesser degree of goodness than any mere human who has the "greater" capacity for refrainings!

In light of all this, I submit that Howsepian simply has the wrong account of "refraining from evil." Here, I believe, is a more adequate account:

(RE) An agent $S$ refrains from an evil action $E$ in circumstance $C$ if (1) $S$ understands that $E$ in $C$ is evil, and (2) $S$ chooses to $\sim E$ in $C$ because $S$ desires not to do an evil action in $\mathrm{C}$.

(RE) does not require that an agent's knowledge of what kind of freedom he has or doesn't have impacts whether or not he can literally refrain from an action. Genuine refrainings simply require that an agent understands that the evil action he refrains from is indeed evil and that he is refraining from it because it is evil. This seems to me to be a perfectly coherent notion of what it means to refrain from evil. What's more, (RE) is consistent with either a compatibilist or libertarian view of freedom. That, I take it, is a virtue.

\section{Rasmussen's Attempt to De-Value GOLF}

Another attempt to justify Plantingian significant freedom that would undermine the possibility and/or feasibility of W and GOLF is presented by Joshua Rasmussen (Rasmussen 2013). He presents his case as a response to the problem of accounting for the value of creaturely freedom to do evil in light of the fact that the saints in heaven have no such freedom. Thus, it might be argued that "[i]f heaven is the best place and no one has moral freedom there, then having moral freedom is not valuable (at any time)" (Ibid., 421). ${ }^{15}$ By "moral freedom" Rasmussen means the freedom to do evil (which I take to be essentially equivalent to Plantinga's significant freedom). Rasmussen argues against this claim by defending the following proposition (I preserve here his numbering ${ }^{16}$ ):

15 This statement is premise (5) in what Rasmussen calls the "Problem of Moral Freedom with respect to heaven."

${ }^{16}$ This proposition appears as (1) in Rasmussesn's printed article (422). However, it is clear from the context that this is a printing error and that he means (7). 
(7) At least some of the goods in heaven depend for their existence on there being persons who had moral freedom.

Rejecting other putative attempts to justify (7), ${ }^{17}$ Rasmussen contends that "moral freedom is a good. . .because it contributes to the value or quality of certain situations that involve free actions" (Rasmussen 2013, 424). More specifically, moral freedom "allows there to be a situation in which a being, such as God, is the object of loving acts without causally determining those very acts" (Ibid., 426). To explain, he offers two scenarios, one involving a case of "forced love" in which Sally causally determines (through the use of a love potion) her husband Sam to express love for her by buying her a vase of flowers; the other a case of "unforced love" in which Sam, of his own accord, freely expresses his love by buying Sally a vase of flowers. Intuitively, the case of unforced love is morally better than the forced love case. Rasmussen attempts to capture this intuition with the following principle:

(L) A situation in which an agent $x$ makes some agent $y$ express love toward $x$ lacks a certain value that's included in a situation in which $x$ is the recipient of an expression of love by $y$ without $x$ making $y$ express love to $x$,

where

" $x$ makes $y$ do $z$ " =def " $x$ performs an action $A$ that is part of a causal chain resulting in a state of the world that (i) necessarily implies that $y$ does $z$ at some time, and (ii) obtains independently of any prior intention of $y$ to do $z$. (Ibid., 425)

So, even though the saints in heaven cannot do evil, if the love they have for God is to be unforced and genuine, then they must have the opportunity prior to their heavenly state to develop such genuine love. And that requires, according to Rasmussen, that the saints possess, at some time prior to heaven, the capacity for moral freedom-i.e., the freedom to do evil. If so, then Rasmussen's argument challenges the plausibility of my world $\mathrm{W}$ and GOLF.

But there are reasons to question Rasmussen's defense of moral freedom. For one thing, Rasmussen appears to create a Straw Man of the compatibilist view that is the direct target of $(\mathrm{L})$. It is telling that his paradigm example of "forced love" involves

\footnotetext{
${ }^{17}$ For example, the attempts of Sennett (1999); and Pawl and Timpe (2009).
} 
an agent who is determined to perform a "loving act" by a love potion. With that example in mind, it is easy to see why many would find (L) acceptable. However, few compatibilists would understand God's determination of human action on the model of a coercive drug. In responding to a very similar scenario, Derk Pereboom writes, "It would seem that what is unacceptable is not being determined by the other party per se, but rather how one is determined, and that there are varieties of determination by the other party that are not objectionable" (Pereboom 2011, 273). Consider this variation on Rasmussen's "Forced-Love" scenario:

(Drawn-Out Love) Sam loves daffodils, and his wife, Sally, knows this. And Sam knows that Sally knows this. Rather than passively wait to see if Sally will decide to buy him daffodils, Sam pours on the charm. He unselfishly serves her from the depths of a virtuous character, performing many loving acts on Sally's behalf. One day, Sally, filled with deep affection for him, says, "Sam, I'm overwhelmed by your love for me. I feel compelled to do something for you in return for all you have done for me." To which Sam responds, "Well, you know what I like, don't you?" Sally buys him daffodils. ${ }^{18}$

We may suppose that Sam's actions meet Rasmussen's conditions for " $x$ makes $y$ do $z$." But it is not at all obvious, as (L) would have it, that the situation so described lacks a certain value that would be included in a similar situation in which $x$ does not make $y$ do $z$. I see this counterexample as analogous to an aesthetic situation in which a person who is aesthetically sensitive is drawn irresistibly to recognize and respond with admiration to a beautiful work of art. None of us think that such "compulsion" (if that's what we want to call it) is unacceptable, unsavory, or in any way "lacking" in value. Likewise, why should we find anything lacking or deficient in the value of an "aesthetic" response to God who showers humans with loving gifts and opens the eyes of people to "behold the beauty of the LORD" (Psalm 27:4), thus drawing them irresistibly to worship and love him? ${ }^{19}$

For another thing, it needs to be seen that Rasmussen's defense of moral freedom runs afoul of the same theological problems that beset Howsepian's view. For example, Jesus, if he is impeccable, lacks moral freedom both now and in his earthly incarnation. Jesus, in his humanity, came to love the Father during his earthly incarnation. Was Jesus' love for the Father while on earth a forced loved? On

18 The reader will notice that the roles in the example have been inverted in comparison with Rasmussen's example. This inversion was done in order to avoid any potential stereotypes that could arise from this new version of the scenario.

${ }^{19}$ For more reasons to think that genuine love does not require libertarian freedom or GOLF, see Ekstrom (2016). 
Rasmussen's terms it might seem so. Well, then, Jesus's love for the Father now that he is in heaven lacks a value that the love for God of each and every merely human saint in heaven has! Surely, that cannot be.

Lastly, Rasmussen's defense of moral freedom, while initially seeming to pose a challenge to world W and GOLF, actually leaves them untouched. In W, the agents who possess GOLF have, by definition, libertarian free will. When they choose between multiple good options, their choices are not determined as in Rasmussen's forced love case. So, in world W, as Greg Welty and I have pointed out elsewhere, "No expression of creaturely love toward God would be an action that God made us perform" (Welty and Cowan 2015). Rasmussen's definition of " $x$ makes $y$ do $z$ " simply does not apply in W. Therefore, in the very nature of the case, Rasmussen's defense of moral freedom leaves world $\mathrm{W}$ and GOLF untouched.

It might be objected, however, that although the GOLF-possessing agents in W are not determined to perform any specific good action, they are nonetheless determined to express love for God in some way since they cannot do evil and not expressing love for God is an evil. But, unless one can show that the "drawn-out love" described above is somehow incoherent or implausible, then why think that a situation in which agents who must somehow express love for God lack some value they would have in a "moral freedom" world? I see no reason to think this.

\section{Conclusion}

We have seen that recent attempts to justify the significant moral freedom required by the FWD fail to undermine the possibility of a world containing libertarianly free creatures who can only choose to do good. While I certainly cannot rule out further potential accounts of the necessity or value of "unrestricted" or "significant" freedom, ${ }^{20}$ I do believe that the current state of the dialectic favors the conclusion that the free will defense is dead. For it seems imminently plausible to suppose that it was feasible for God to have created a possible world in which creatures with libertarian freedom never go wrong, namely, a world containing creatures who "play" GOLF.

${ }^{20}$ I should mention that Kevin Timpe has recently attempted to rule out GOLF-worlds (Timpe 2014), writing, for example, that a human being, in order to be morally responsible for his moral character, "must have the time to develop such a character" and that "[M]oral freedom [i.e., the freedom to choose between good and evil alternatives] for creaturely agents is a necessary condition for creatures to freely form a moral character" (108). I have previously responded to Timpe, showing that he is engaged in mere assertion and not offering an argument for this claim at all (See Cowan 2016). 


\section{Bibliography}

Cowan, S. B. 2003. "The Grounding Objection to Middle Knowledge Revisited." Religious Studies 39(1): 93-102. https://doi.org/10.1017/S0034412502006352.

Cowan, S. B. 2009. "Molinism, Meticulous Providence, and Luck." Philosophia Christi 11(1): 156-69. https://doi.org/10.5840/pc200911111.

Cowan, S. B. 2016. “God, Heavenly Freedom, and Evil: A Further Response to Paw1 and Timpe," Evangelical Philosophical Society website article https://www.epsociety.org/userfiles/Cowan-

God\%20Heavenly\%20Freedom\%20and\%20Evil\%20(final).pdf.

Cowan, S. B. and G. A. Welty. 2015. "Pharaoh's Magicians Redivivus: A Response to Jerry Walls on Christian Compatibilism." Philosophia Christi 17(1): 151-73. https://doi.org/10.5840/pc20151719.

Davis, R. B., and W. P. Franks. 2018. "Plantinga's Defense and His Theodicy Are Incompatible." In Does God Matter? Essays on the Axiological Consequences of Theism, ed. Klaas J. Kraay. New York: Routledge, 203-23. https://doi.org/10.4324/9781315210995-11.

Ekstrom, L. W. 2016. "The Cost of Freedom." In Free Will and Theism: Connections, Contingencies, and Concerns, ed. K. Timpe and D. Speak. Oxford University Press, 62-78. https://doi.org/10.1093/acprof:oso/9780198743958.003.0004.

Flint, T. P. 2001. "'A Death He Freely Accepted': Molinist Reflections on the Incarnation." Faith and Philosophy 18(1): 3-20.

https://doi.org/10.5840/faithphil20011819.

Flint, T. P. 2006. Divine Providence: The Molinist Account. Cornell University Press.

Geach, P. 1987. Truth and Hope. Notre Dame University Press.

Grant, W. M. 2019. Free Will and God's Universal Causality: A Dual Sources Account. London: Bloomsbury. https://doi.org/10.5040/9781350082939.

Howsepian, A. A. 2008. "What's So Good about Libertarian Free Will." Philosophia Christi 10(1): 201-17. https://doi.org/10.5840/pc200810112.

Leftow, B. 2014. "Tempting God." Faith and Philosophy 31(1): 3-23. https://doi.org/10.5840/faithphil201312301.

Mackie, J. L. 1955. "Evil and Omnipotence." Mind 64: 200-212. https://doi.org/10.1093/mind/LXIV.254.200.

McKinley, J. E. 2011. “Four Patristic Models of Jesus Christ's Impeccability and Temptation." Perichoresis 9(1): 29-66.

Murray, M. 2002. Review of Truth and Hope. Notre Dame Philosophical Reviews. http://ndpr.nd.edu/news/23380-truth-and-hope-the-furst-franz-joseph-und- 
furstin-gina--lectures-delivered-at-the-international-academy-of-philosophy1998/. Accessed December 11, 2018.

Otte, R. 2009. "Transworld Depravity and Unobtainable Worlds." Philosophy and Phenomenological Research 78(1):165-177. https://doi.org/10.1111/j.19331592.2008.00236.x.

Pawl, T., and K. Timpe. (2009) "Incompatibilism, Sin, and Free Will in Heaven." Faith and Philosophy 26(4): 398-419. https://doi.org/10.5840/faithphil200926437.

Pereboo, D. 2011. "Theological Determinism and Divine Providence." In Molinism: The Contemporary Debate, ed. Ken Perszyk. New York: Oxford University Press, 262-79. https://doi.org/10.1093/acprof:oso/9780199590629.003.0017.

Plantinga, A. 1974. God, Freedom, and Evil. New York: Harper and Row.

Plantinga, A. 2005. "Supralapsarianism, or 'O Felix Culpa'." In Christian Faith and the Problem of Evil, ed. Peter van Inwagen. Grand Rapids: Eerdmans, 1-25.

Pruss, A. 2012. "A Counterexample to Plantinga's Free Will Defense." Faith and Philosophy 29(4): 400-415. https://doi.org/10.5840/faithphil201229442.

Rasmussen, J. 2013. “On the Value of Freedom to Do Evil." Faith and Philosophy 30(4): 418-28. https://doi.org/10.5840/faithphil201330437.

Sennett, J. 1999. "Is There Freedom in Heaven?" Faith and Philosophy 16(1): 69-82. https://doi.org/10.5840/faithphil19991617.

Tenenbaum, S. 2013. The International Encyclopedia of Ethics, ed. Hugh LaFollette. Bridgewater, NJ: Wiley. S.v. "Guise of the Good." https://doi.org/10.1002/9781444367072.wbiee659.

Timpe, K. 2014. Free Will in Philosophical Theology. London: Bloomsbury.

Timpe, K. and D. Speak, eds. 2016. Free Will and Theism: Connections, Contingencies, and Concerns. Oxford University Press, 2016. https://doi.org/10.1093/acprof:oso/9780198743958.001.0001.

Walls, J. L. 2015. "Pharaoh's Magicians Foiled Again: A Reply to Cowan and Welty." Philosophia Christi 17(2): 411-26. https://doi.org/10.5840/pc201517234.

Welty, G. A. 2020. Review of Free Will and God's Universal Causality: The Dual Source Account. Philosophia Christi 22(1):159-64. https://doi.org/10.5840/pc202022111.

Welty, G. A., and S. B. Cowan 2015. "Won't Get Foiled Again: A Rejoinder to Jerry Walls." Philosophia Christi 17(2): 427-42. https://doi.org/10.5840/pc201517235.

Published Online: December 9, 2021 